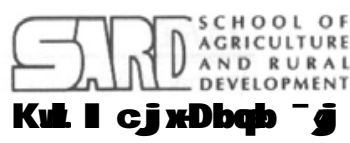

Available online at http: / / www.banglajol.info/index.php/jard
J ARD

Journal of Agriculture \& Rural Development

\title{
Effect of Some Containers, Chemicals and Indigenous Materials on Incidence of Wheat Pests in Storage
}

\author{
M. Y. Ali, M. A. LATIF ${ }^{*} \&$ M. Ali \\ Department of Entomology, Sher-e-Bangla Agricultural University, Sher-e-Bangla Nagar, Dhaka, \\ Bangladesh
}

\begin{abstract}
The experiment was conducted to evaluate the effect of some containers, chemicals and indigenous materials for protection of wheat seed in storage at the Entomology Laboratory of Sher-e-Bangla Agricultural University (SAU), Dhaka. Wheat seeds were stored in four types of containers (Tin kouta, earthen pot, plastic container and gunny bag) with two types of chemicals (Naphthalene and camphor) and two indigenous materials (neem leaf powder and sand). Among the different containers, the lowest population of grain moth (1.40-7.93), red flour beetle (6.40-35.33) and rice weevil (0.20-9.13) was recorded from the plastic containers. At the initial stage of storage, grain moth was dominant but red flour beetle was abundant at the middle and later stage of storage. Population of rice weevil was gradually increased with storage period. Considering the storage materials, the lowest population of grain moth (3.92-28.98), red flour beetle (7.58-43.08) and rice weevil (0.75-9.08) was found in naphthalene. Camphor had the similar population level of those three insect pests during the study period.
\end{abstract}

Key words: Grain moth, rice weevil, red flour beetle, neem leaf powder, camphor and naphthalene.

\section{INTRODUCTION}

Wheat (Triticum aestivum L.) is the most widely grown food crop in the world, which ranks first in terms of area and production in the world (FAO 1988). It is stored in the government and public godown both in Bangladesh and developed countries. A considerable amount of wheat as well as other grains is lost every year in storage. Both biotic and abiotic factors are responsible for the loss of wheat in storage. The major biotic factors influencing wheat loss during storage are insects, moulds, birds and rats (Baloch et al. 1994). There are approximately 200 species of insect and mite species attacking stored grains and stored products (Maniruzzaman 1981). Gentile and Trematerra (2004) reported that twenty insect pests infested stored wheat while Chaudhary and Mahla (2001) observed 10 insect species of wheat in storage. Their attacks reduced both quantity and food value of stored seed (Kabir 1978).

In Bangladesh, most of the farmers are poor and marginal and store small quantities of wheat grains in their house for consumption and seed purpose. They store wheat in tin kouta, earthen pot

\footnotetext{
* Corresponding author: Associate Professor, Department of Entomology, Sher-e-Bangla Agricultural University, Sher-e-Bangla Nagar, Dhaka, Bangladesh, E-mail: mdalatif15@yahoo.com

(C) 2009 School of Agriculture and Rural Development, Bangladesh Open University, All rights reserved.
} 
or motka, iron or metal container, plastic container, gunny bag and thick polythene bag. They use various indigenous materials such as sand, lime, neem leaf, and cheap chemicals like naphthalene, camphor etc for storing of wheat. So, they need some cheap, easy to use and readily available but effective methods for safe storing of wheat. Neem leaf powder and sand are locally available indigenous source of materials with low or no mammalian toxicity and no adverse effect on seed germination, cooking quality and milling. These indigenous materials have been used for insect pest management for more than a century in India (Kabir et al. 2003, Prakash et al. 1987). Abivardi and Benz (1984) reported that camphor is a natural component of essential oil having very low mammalian toxicity. It was found highly effective against rice weevil (Latif et al. 2004, Kabir et al. 2003) as well as maize weevil (Latif and Rahman 2000). Moreover, naphthalene is a cheap and easily available chemical, which was effective against different stored grain pests (Latif et al. 2004, Kabir et al. 2003). So, it is important to know the effect of such containers and storage materials on incidence of insect pest of wheat for easy and cheap storage but few studies have been done regarding these. Therefore, the present study was undertaken to search the suitable and cheap storage containers and materials for storing of wheat grains.

\section{MATERIALs And Methods}

The study was conducted in the laboratory of the Department of Entomology, Sher-e- Bangla Agricultural University (SAU), Dhaka during April 2006 to November 2006. Clean and healthy seed of wheat variety "Kanchan" was used as stored grain in this experiment. On the other hand, tin kouta, plastic containers, earthen pots and gunny bags were selected as storage containers, neem leaf powder and sand as indigenous materials camphor and naphthalene as chemicals. Containers were purchased from the local market of Chakbazar, Dhaka. Fresh green neem leaves were collected, washed, air dried and then dried in the oven at $50^{\circ} \mathrm{C}$ for 24 hours and dried leaves were powdered with electric grinder. Sand was collected, cleaned, air dried and then sieved to remove the inert materials. Camphor and naphthalene were collected from Krishi Market, Mohammadpur, Dhaka. Wheat seed was collected from Bangladesh Agricultural Development Corporation (BADC), Dhaka centre and dried in the open sun light for two days.

\section{Treatments and design}

The experiment was laid out in Factorial Design having two factors with three replications. Various containers were considered as one factor and different materials and chemicals were considered as another factor. Four types of container such as tin kouta, earthen pots, plastic containers and gunny bag indicate the four levels of one factor. On the other hand, two chemicals camphor and naphthalene, two indigenous materials neem leaf powder and sand, and an untreated control indicate the five levels of the other factor. Therefore, a total of $20(4 \times 5)$ treatment combinations and $60(4 \times 5 \times 3)$ experimental units were used in this experiment.

\section{Test procedure}

For this experiment, two kilograms dry wheat seeds were kept in each of the previously marked 60 containers. Then neem leaf powder $(10 \mathrm{~g} / \mathrm{kg})$, sand $(100 \mathrm{~g} / \mathrm{kg})$, camphor $(4 \mathrm{~g} / \mathrm{kg})$ and naphthalene $(4 \mathrm{~g} / \mathrm{kg})$ were added to the grains in the respective marked container. Neem leaf powder, sand, camphor and naphthalene were placed in 3 (three) layers in the containers. At first, one third of neem leaf powder, sand, camphor and naphthalene was placed in the bottom of the respective marked container, and then half of the grains was placed in the container. Again one third neem leaf powder, sand, camphor and naphthalene was kept on upper layer of the grains. The rest of the grains were placed in the respective mark containers and finally one third neem leaf powder, sand, camphor and naphthalene were placed on the upper surface of the grains in the containers. Nothing except grains was kept to the respective untreated control. The open end of each of the containers was closed by its cover and gunny bag was closed tightly with rope.

\section{Recording of insect}

Data collection was started after two months of storage on 1st week of June and continued up to November at one month interval. For grain moths, a cylindrical insect holder made of mosquito net 
was placed upper side of the containers and shaken frequently. So that all the moths flew up and was captured in the net. Then the moths were killed with ethyl acetate to count their number. For other insects, three samples were collected with a sampling probe from each container. Samples were collected from lower, middle and upper layer of the grain and thoroughly mixed. Insect pests in each sample were properly identified and their population was counted and recorded.

\section{Data analysis}

All of the collected data were subjected to square root transformation as and when needed and were analyzed by using MSTAT statistical package programme applicable for the Factorial Randomized Completely Block Design (RCBD). Means were separated by Duncan's Multiple Range Test (DMRT).

\section{Results AND Discussion}

The study revealed that three insect pests such as grain moth (Sitotroga cerealella), red flour beetle (Tribolium castaneum), and rice weevil (Sitophilus oryzae) attacked wheat seriously during the study period. Among the different containers, the lowest population of grain moth was observed in plastic containers (1.40-7.93) during the study period (Table 1). However, the number of grain moth was statistically identical with that of the tin kouta (1.93-14.67). The highest number of grain moth (99.07) was observed in the plastic container in July. Analysis of the Table 1 reveals that the lowest population (6.40-35.33) of red flour beetle was recorded in plastic container throughout the study period, which was statistically similar with that of the tin kouta (6.93-44.27). The number of red flour beetle was always higher (24.60-80.80) in gunny bag during the study period followed by earthen pot (15.87-70.73). Table 1 further expresses that the number of rice weevil was found lowest $(0.20-9.13)$ in plastic container during the study period followed by $(0.40-10.07)$ tin kouta having no significant difference between them. The population of rice weevil was significantly higher in gunny bag (1.73-19.07), which was statistically identical with earthen pot (2.00-14.20). Figure 1 also illustrates the comparative abundance of grain moth, red flour beetle and rice weevil in gunny bag during the study. Initially the population of grain moth was high but at the middle stage red flour beetle was higher than grain moth and rice weevil. The red flour beetle population was always significantly higher than rice weevil population during the study period. Although the weevil population increased gradually but its highest population was lower than that of the red flour beetle in October. Therefore, grain moth was the most abundant insect pests initially and red flour beetle was abundant throughout the study period.

Table 1. Population of grain moth, red flour beetle and rice weevil in different containers

\begin{tabular}{|c|c|c|c|c|c|c|}
\hline \multirow[t]{2}{*}{ Containers } & \multicolumn{6}{|c|}{ Number of grain moths } \\
\hline & June & July & August & Septembel & October & November \\
\hline Tin kouta & $1.93 \mathrm{a}$ & $11.07 \mathrm{a}$ & $14.67 \mathrm{~b}$ & $8.73 \mathrm{a}$ & $6.00 \mathrm{a}$ & $2.47 \mathrm{a}$ \\
\hline Earthen pot & $53.07 \mathrm{~b}$ & $51.87 \mathrm{~b}$ & $51.87 \mathrm{c}$ & $25.13 b$ & $19.33 \mathrm{~b}$ & $7.87 \mathrm{~b}$ \\
\hline Plastic container & $2.20 \mathrm{a}$ & $7.93 \mathrm{a}$ & $5.40 \mathrm{a}$ & $7.33 \mathrm{a}$ & $4.86 \mathrm{a}$ & $1.40 \mathrm{a}$ \\
\hline \multirow[t]{2}{*}{ Gunny bag } & $93.73 \mathrm{c}$ & $99.07 \mathrm{c}$ & $55.93 \mathrm{~d}$ & $38.20 \mathrm{c}$ & $27.87 \mathrm{c}$ & $12.80 \mathrm{c}$ \\
\hline & \multicolumn{6}{|c|}{ Number of red flour beetles } \\
\hline Tin kouta & $14.07 \mathrm{a}$ & $19.73 \mathrm{a}$ & $44.27 \mathrm{~b}$ & $25.33 \mathrm{a}$ & $17.33 \mathrm{a}$ & $6.93 \mathrm{a}$ \\
\hline Earthen pot & $25.4 \mathrm{~b}$ & $41.87 \mathrm{c}$ & $70.73 \mathrm{c}$ & $41.33 \mathrm{~b}$ & $30.13 b$ & $15.87 \mathrm{~b}$ \\
\hline Plastic container & $14.73 \mathrm{a}$ & $27.20 \mathrm{~b}$ & $35.33 \mathrm{a}$ & $22.47 \mathrm{a}$ & $15.47 \mathrm{a}$ & $6.40 \mathrm{a}$ \\
\hline \multirow[t]{2}{*}{ Gunny bag } & $27.47 \mathrm{~b}$ & $57.20 \mathrm{~d}$ & $80.80 \mathrm{~d}$ & $47.20 \mathrm{c}$ & $36.27 \mathrm{c}$ & $24.60 \mathrm{c}$ \\
\hline & \multicolumn{6}{|c|}{ Number of rice weevils } \\
\hline Tin kouta & $0.40 \mathrm{a}$ & $1.73 \mathrm{a}$ & $5.60 \mathrm{a}$ & $7.93 \mathrm{a}$ & $10.07 \mathrm{a}$ & $8.07 \mathrm{a}$ \\
\hline Earthen pot & $2.00 \mathrm{~b}$ & $4.20 \mathrm{~b}$ & $8.27 \mathrm{~b}$ & $10.40 \mathrm{~b}$ & $14.20 \mathrm{~b}$ & $13.40 \mathrm{~b}$ \\
\hline Plastic container & $0.20 \mathrm{a}$ & $2.47 \mathrm{a}$ & $6.00 \mathrm{a}$ & $6.80 \mathrm{a}$ & $9.13 \mathrm{a}$ & $6.94 \mathrm{a}$ \\
\hline Gunny bag & $1.73 \mathrm{~b}$ & $4.74 \mathrm{~b}$ & $10.43 \mathrm{~b}$ & $13.40 \mathrm{~b}$ & $19.07 \mathrm{c}$ & $16.13 \mathrm{~b}$ \\
\hline
\end{tabular}

Means in the column followed by the same letter(s) are statistically identical at $1 \%$ level by DMRT. 
M. Y. Ali et al.

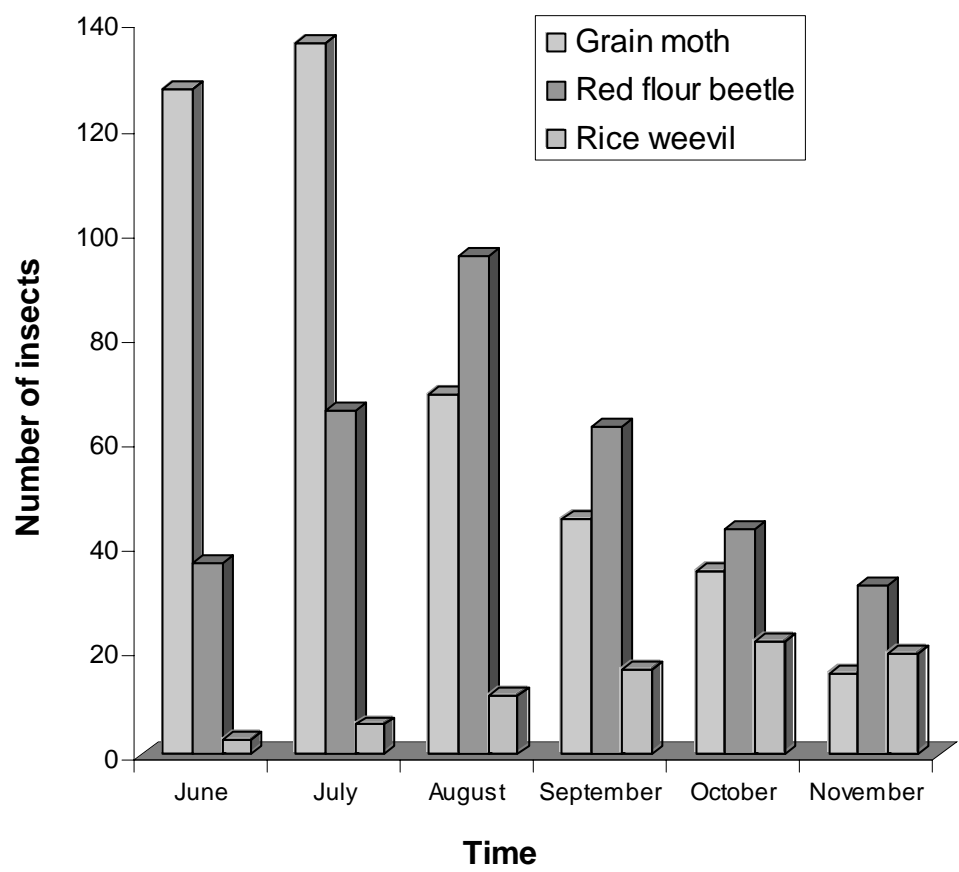

Figure 1. Comparative abundance of grain moth, red flour beetle and rice weevil in gunny bag.

The results of the present study indicate that wheat was attacked by three major insect pests during the period from June to November. Among the containers plastic container provided the highest protection of wheat from insect attack and tin kouta showed the similar effectiveness. Considering all the containers, the trend in the protection of wheat grain from insect population showed the following decreasing order, plastic container>tin kouta>earthen pod>gunny bag. The results thus obtained in the present study supported the finding obtained by several researchers (Hamel et al. 1999, Samuels and Modgil 1999, Karim 1987), who reported that wheat was attacked by rice weevil (Sitophilus oryzae), grain moth (Sitotroga cerealella) and red flour beetle (Tribolium castaneum). On the other hand Gentile and Trematerra (2004) stated that grain moth, Sitotroga cerealella was the major insect pests of wheat in storage. While, Chaudhury and Mahla (2001) reported 10 insect pest of wheat in storage and these 3 species were also found as major in storage. Although the number of wheat attacking species varied but it was logical because the abundance of major insects may be varied with climatic zones. The highest number of insect pests in gunny bags indicates its lower efficacy for protecting the grain against insect infestation. Baloch et al. (1994) observed the similar results and concluded that jute bag increased the risk of insect infestation. Similar high level of infestation in gunny bags were also observed by Singh (2001) in stored wheat. However, Kabir et al. (2003) reported that gunny bag with polythene reduced the insect infestation. The high porosity of gunny bag provided better aeration for the different insect pests, which increased the moisture content of the grain and facilitated higher infestation. However, among the four different containers tin kouta and plastic containers showed the best performance in protecting the grain. These findings supported the results obtained by Kabir et al. (2003). Tin kouta and plastic containers prevented aeration as well as kept the moisture percentage of the grain unchanged and prohibited the population growth of insect pests. Prakash (1982) reported that high moisture content facilitated insect infestation in storage. The population trends of the three insect pests in gunny bag indicate that the population of grain moth gradually increased and reached to the peak in July and then declined. In contrast, rice weevil population was low in early 
stage and gradually increased and reached to the highest level in October. The similar trend of population of grain moth and rice weevil was reported by Alam (1971) and Prakash (1982). The lowest population of grain moth at early stage indicates its lower infestation, which supports the findings of Metcalf and Flint (1962) and Alam (1971), who stated the lower level of infestation of the beetle at early stage and they also observed that neither grub nor adult could generally damage whole or intact grains but they fed on grains only, which had already been damaged by other pests. Moreover, Walter (1990) reported that fed flour beetles may be present in large numbers in infested grain, but are unable to attack sound or undamaged grain.

The effect of different indigenous materials and chemicals on incidence of grain moth, flour beetle and rice weevil during the study period are shown in Table 2. Significantly the lowest population of grain moth (3.92-28.98) was observed in naphthalene followed by $5.17-30.08$ in camphor having no significant difference between them. In contrast, the highest population of grain moth (7.92-58.67) was observed in untreated control followed by 7.25-54.00 and 6.48-47.58 in sand and neem leaf powder respectively. The population trend of red flour beetle during the study period indicates that the lowest number of the beetle was found in naphthalene (7.58-43.08) which was statistically identical with that of the camphor (Table 2). Similarly, the minimum population of rice weevil (0.75-9.08) was recorded from naphthalene followed by $0.92-11.58$ in camphor having no significant difference between them. However, the highest number of rice weevil was observed in control (1.33-15.67), which was statistically identical with sand and neem leaf powder.

Table 2. Population of grain moth, red flour beetle and rice weevil in different indigenous materials and chemicals

\begin{tabular}{lcccccc}
\hline Treatments & \multicolumn{5}{c}{ Number of grain moths } \\
\cline { 2 - 7 } & June & July & August & September & October & November \\
\hline Neem leaf powder & $47.58 \mathrm{~cd}$ & $42.83 \mathrm{~b}$ & $37.25 \mathrm{~b}$ & $21.50 \mathrm{bc}$ & $16.17 \mathrm{~cd}$ & $6.48 \mathrm{bc}$ \\
Sand & $54.00 \mathrm{~d}$ & $53.08 \mathrm{~cd}$ & $38.00 \mathrm{c}$ & $24.33 \mathrm{c}$ & $18.58 \mathrm{~d}$ & $7.25 \mathrm{~cd}$ \\
Camphor & $23.25 \mathrm{a}$ & $30.08 \mathrm{a}$ & $23.42 \mathrm{a}$ & $15.50 \mathrm{a}$ & $10.50 \mathrm{ab}$ & $5.17 \mathrm{bc}$ \\
Naphthalene & $17.17 \mathrm{ab}$ & $28.98 \mathrm{a}$ & $20.75 \mathrm{a}$ & $13.58 \mathrm{a}$ & $8.75 \mathrm{a}$ & $3.92 \mathrm{a}$ \\
Untreated control & $58.67 \mathrm{~d}$ & $57.50 \mathrm{~d}$ & $40.42 \mathrm{c}$ & $24.33 \mathrm{c}$ & $18.58 \mathrm{~d}$ & $7.92 \mathrm{~cd}$ \\
\hline & \multicolumn{5}{c}{ Number of red flour beetles } \\
\hline Neem leaf powder & $27.42 \mathrm{c}$ & $42.17 \mathrm{~b}$ & $61.25 \mathrm{~b}$ & $39.25 \mathrm{~b}$ & $26.08 \mathrm{c}$ & $15.50 \mathrm{c}$ \\
Sand & $22.33 \mathrm{~b}$ & $48.42 \mathrm{c}$ & $67.08 \mathrm{~b}$ & $38.17 \mathrm{~b}$ & $29.08 \mathrm{c}$ & $16.58 \mathrm{c}$ \\
Camphor & $13.25 \mathrm{a}$ & $31.50 \mathrm{a}$ & $50.92 \mathrm{a}$ & $25.75 \mathrm{a}$ & $22.42 \mathrm{~b}$ & $10.33 \mathrm{~b}$ \\
Naphthalene & $11.58 \mathrm{a}$ & $26.58 \mathrm{a}$ & $43.08 \mathrm{a}$ & $22.58 \mathrm{a}$ & $16.75 \mathrm{a}$ & $7.58 \mathrm{a}$ \\
Untreated control & $27.50 \mathrm{c}$ & $46.33 \mathrm{c}$ & $66.58 \mathrm{~b}$ & $44.67 \mathrm{c}$ & $29.67 \mathrm{c}$ & $17.25 \mathrm{c}$ \\
\hline & & \multicolumn{5}{c}{ Number of rice weevils } \\
\hline Neem leaf powder & $1.08 \mathrm{~b}$ & $4.08 \mathrm{~b}$ & $7.83 \mathrm{~b}$ & $9.83 \mathrm{bc}$ & $14.08 \mathrm{~b}$ & $12.58 \mathrm{~b}$ \\
Sand & $1.33 \mathrm{~b}$ & $4.00 \mathrm{~b}$ & $8.75 \mathrm{~b}$ & $11.83 \mathrm{c}$ & $15.17 \mathrm{~b}$ & $13.92 \mathrm{~b}$ \\
Camphor & $0.92 \mathrm{a}$ & $2.67 \mathrm{a}$ & $6.58 \mathrm{a}$ & $8.25 \mathrm{a}$ & $11.58 \mathrm{a}$ & $7.75 \mathrm{a}$ \\
Naphthalene & $0.75 \mathrm{a}$ & $2.08 \mathrm{a}$ & $6.08 \mathrm{a}$ & $6.75 \mathrm{a}$ & $9.08 \mathrm{a}$ & $7.75 \mathrm{a}$ \\
Untreated control & $1.33 \mathrm{~b}$ & $3.58 \mathrm{~b}$ & $8.25 \mathrm{~b}$ & $11.50 \mathrm{c}$ & $15.67 \mathrm{~b}$ & $13.67 \mathrm{~b}$ \\
\hline
\end{tabular}

Means in the column followed by the same letter(s) are statistically identical at $1 \%$ level by DMRT.

The results of the present study indicate that naphthelene and camphor provided the highest efficacy in protecting wheat from the insect pests in storage. Considering all the materials, the trend in the protection of wheat grain from insect population showed the following decreasing order: naphthalene> camphor $>$ neem leaf powder $>$ sand. The effectiveness of naphthelene and camphor thus obtained in the present findings supported the results obtained by several researchers (Latif et al. 2004, Siddika 2004, Kabir et al., 2003). Latif et al. (2004) stated that camphor provided more than 90\% efficacy against the rice weevil. While Siddika (2004) reported that the camphor significantly reduced the infestation of wheat pest in storage. On the other hand Kabir et al. (2003) reported that naphthalene and camphor showed the best performance in protecting mung bean against insect pests in storage. Although the neem leaf powder and sand showed some efficacy in 
protecting the wheat against insect pests but their effect was not satisfactory. These results were different from that of the findings observed by some researchers (Facknath and Sunita 2006, Chawdhury and Mahla 2001, Chatterjee 1984). Facknath and Sunita (2006) reported that neem leaf extract (Azadirachta indica A. Juss.) reduced insect populations in stored products through its toxic and growth disrupting and other effects on the pests. Chaudhury and Mahla (2001) observed that a layer of 2 and $3 \mathrm{~cm}$ sand over the grain were the most effective with regard to poor oviposition emergence, development and less damage to seed of bengal gram (Cicer arietinum). However, the findings of the study was in conformity with findings obtained by Kabir et al. (2003), who found that neem leaf powder and sand showed some efficacy in protecting mung bean against Callosobruchus chinensis L. in storage. The results of this study may differ with that of the other researchers however it is logical because the efficacy of neem leaf powder and the efficacy of leaf extract may vary against different pests. From these results, it may be concluded that either plastic container or tin kouta with naphthalene or camphor may be used for storage of wheat.

\section{LiteratuRE CiTED}

Abivardi, C. and Benz, G. 1984. New observation on camphor an old insect repellent as a relatively safe candidate fumigant against nine insect species. Mitteilunger der Schweizerischen Entomologischan Gesellschaft. 57(2-3), 179-187.

Alam, M. Z. 1971. Pest of stored grains and other stored products and their control. Agricultural Information Service, Dhaka. 61p.

Baloch, U. K., Grapher, B. K. and Ricco, G. D. 1994. Loss Assessment and Loss Prevention in Wheat Storage in Pakistan. CAB International. 922p.

Chatterjee, S. 1984. Effect of some inert dusts on Trogoderma granaria Evert. Indian J. Ent. 16, 423-425.

Chaudhury, S. D. and Mahla, J. C. 2001. Insect pests infesting stored wheat in different climatic regions of Haryana. Crop Res. Hisar. 2(3), 384-386.

Facknath, J. and Sunita, D. 2006. Combination of neem and physical disturbance for the control of four insect pests of stored products. Intern. J. Trop. Insect Sci. 26(1), 16-27.

FAO (Food and Agricultural Organization). 1988. Global survey of pesticide susceptibility of stored grain pests. Report of the $9^{\text {th }}$ session of the FAO working party of experts on pest resistance to pesticides, June 18-22. Rome, Italy. 17p.

Gentile, P. and Trematerra, P. 2004. Insect pests of hulled wheat and ecology of Sitotroga cerealella (Olivier). Technica Molitoria. 55(9), 855-862.

Hamel, D., Pliestic, S. and Dobricevic, N. 1999. The most common insect pests of stored wheat and their control. Zbornik Radova. 15, 71-75.

Kabir, A. K. M. F. 1978. Pests of grain legumes and their control in Bangladesh. pp. 33-36. In: Singh, S. R., Van Emden, H. F.and Taylor, T. A. (eds.). "Pests of grain legumes: ecology and control". Academic Press. London.

Kabir, K. H., Raman, M. A. and Ahmed, M. S. 2003. Utilization of different containers, chemicals and indigenous materials for the management for the management of pulse beetle (Callosobruchus chinensis L.) in storage. Annual Report, Entomology Division, Bangladesh Agricultural Research Institute, Joydebpur, Gazipur. pp. 67-71.

Karim, M. A. 1987. Insect and vertebrate pests of wheat in the field and in storage and their control. Lecture sheet, Training cum Workshop in wheat. Bangladesh Agriculture Research Institute, Joydevpur, Bangladesh.

Latif, M. A. and Rahman, M. M. 2000. Efficacy of camphor in protecting rice grains infested by rice weevil (Sitophilus oryzae Linn.) in storage. J. Agric. Sci. Tech. 1(1), 65-69. 
Latif, M. A., Rahman, M. M. and Alam, M. Z. 2004. Efficacy of camphor in protecting rice grains infested by rice weevil (Sitophilus oryzae Linn.) in storage. J. Agric. Educ. Technol. 7(1\&2), 75-78.

Maniruzzaman, F. M. 1981. Plant protection in Bangladesh. Natonal Book Centre. 67/A, Purana Paltan. 325p.

Metcalf, C. L. and Flint, W. P. 1962. Destructive and useful insects; their habits and control. Mcgraw Hill Publication. 1072p.

Prakash, A. 1982. Factor affecting losses due to insects and their management in rice storage ecosystem. In: Proceding of National symposium on insect ecology and resource management, organized by Uttar Pradesh Zoological society, held at Mujaffarnagar (UP) on 2-4 Oct. pp. 50-54.

Prakash, A., Rao, J., Pasalu, I. C. and Mathur, K. C. 1987. Rice storage and insect pest management. B. R. Publishing Corporation. New Delhi, India. 350p.

Samuels, R. and Modgil, R. 1999. Biological utilization of insect infested wheat stored in different storage structure. College Home Science, Dept. Food Science and Nutrition, India. 43(5), 336-338.

Siddika, A. 2004. Efficacy of some additives for suppressing Rice moth (Sitotroga cerealella) in stored rice. M.S. Thesis Bangabandhu Sheikh Mujibur Rahman Agricultural University, Gazipur. 64p.

Singh, U. 2001. A study on the prevalent storage structures in the rural households of North Bihar. Indian J. Agric. Res. 35(2), 85-89.

Walter, V. E. 1990. Stored product pests. In: Story, K. and D. Moreland (eds.) Handbook of Pest Control. Frahzak \& Foster Co., Cleveland, OH. pp. 526-529. 